\title{
A Cross-cultural Comparison of Interpersonal Violence in the Lives of College Students from Two Colleges from The Bahamas and United States of America
}

\author{
William J. Fielding \\ The College of The Bahamas ${ }^{1}$ \\ Christina Risley-Curtiss \\ Travis W. Cronin \\ Arizona State University
}

\section{ABSTRACT}

There is a dearth of studies that compare interpersonal violence cross nationally. This paper reports the findings of a cross-sectional study which compares and contrasts violence in the lives of 740 college students, as children and as adults, in The Bahamas and the United States of America. Overall, students in The Bahamas were subjected to more violence (more frequently spanked) than their American counterparts. Frequency of spanking when the student was a preteen and teenager were linked to anger outbursts in adulthood, and higher numbers of anger outbursts were linked with violent behaviours of students. Although Bahamian students were exposed to more violence than the American students, this did not result in Bahamian students being more violent than American students in interpersonal relationships. However, Bahamian students were more likely than American students to anticipate using corporal punishment on their children and to condone violence in marital relationships.

\section{INTRODUCTION}

The peaceful image projected by The Bahamas today masks a violent history. Like other territories in the West Indies, The Bahamas has emerged from invasion, colonization, and slavery into a modern small island state, with limited resources beyond that of sun, sea and sand; these resources underpin the country's tourism industry (Craton \& Saunders, 1999, 2000). In common with its West Indian neighbours, The Bahamas has not dissociated itself from its violent past. Violence in The Bahamas has continued to increase (United Nations Office

\footnotetext{
${ }^{1}$ W. J. Fielding, Director of Planning, The College of The Bahamas; Christina Risley-Curtiss, School of Social Work, Travis W. Cronin, School of Social Work, Arizona State University.

Acknowledgments: We would like to thank Elisa Kawam for her assistance with the data collection and Jennifer Brougham for access to her classes. We would also like to thank Cliff Flynn for his generosity in giving us use of his original questionnaire.

Corresponding author: william.fielding@cob.edu.bs

APA reference: Fielding, W. J., Risley-Curtiss, C., \& Cronin, T. W. (2015). A cross-cultural comparison of interpersonal violence in the lives of college students from two colleges from The Bahamas and United States of America. The International Journal of Bahamian Studies, 21(1), 38-56. https://doi.org/ 10.15362/ijbs.v21i1.230
} 
on Drugs and Crime \& World Bank, 2007), most notably in the increasing number of people who suffer violent deaths each year (Le Franc, Samms-Vaughan, Hambleton, Fox, \& Brown, 2008; Hanna, 2011). Even homicide rates in The Bahamas are 6.3 times higher than in the United States of America (United Nations Office on Drugs and Crime, 2013), despite the United States of America being a country which is well-known for gun violence (National Institute of Justice, 2013) and high prison populations driven by violent crime (O'Hear, 2013).

However, less obvious violence, namely violence in homes and how it affects household members, particularly children, is also important as it can have far-reaching effects (Holt, Buckley, \& Whelan, 2008; Mass, Herrenkohl, \& Sousa, 2008). In Jamaica, poor parenting practices have been implicated as an important factor contributing to the level of violence in that country (Smith \& Mosby, 2003). By extension, the use of violence by parents to discipline children, common in The Bahamas (Brennen et al., 2010), threatens the wellbeing of the entire community, both in the short and long term as abused children may struggle to become productive members of society in adulthood. Further, abused children can have difficulty in their interactions with others (Lazenbatt, 2010), which can lead to further violence. Indeed, child abuse can have effects which transcend generations (Child Welfare Information Gateway, 2013).

The consequences of violence exist in a cultural context; for example, the acceptability of parents spanking children (D’Avanzo, 2008) or the right to own a firearm distinguish cultures (e.g., see Huemer, 2003) and so we need to be aware of historical and current contexts in particular communities. A clear difference between the United States and The Bahamas is captured in their Human Development Index rankings, of
5 and 51 respectively (United Nations Development Prorogramme, 2015). Differences can also exist within a wider national community. For example in the United States, African-American males are 8.2 times more likely to die by homicide than their white male counterparts (Violence Policy Center, 2014). Accordingly, we need to be cognizant of influences beyond just geography which can influence violence in today's society.

The Bahamas is culturally influenced by the United States through the media and interactions arising from entertaining American tourists. Over 500,000 tourists arrive in the Bahamas per month (Trading Economics, 2015), the bulk of whom are North Americans. American news, entertainment and radio and TV stations also increase awareness of the American worldview in The Bahamas. Florida is a focal point for residents of The Bahamas travelling outside the country. In The Bahamas, the United States currency is used interchangeably with Bahamian currency. In 2007, when the United States changed the date when Day Light Saving time occurred, The Bahamas followed suit (2007 Daylight Saving Time Change FAQ). Therefore, in various and often subtle ways, the United States has become the frame of reference for many in The Bahamas. This suggests that it is therefore not inappropriate to conduct a cross-cultural study to compare levels of violence in Bahamian and American homes the purpose of this paper. But while there are clear connections between the United States of America and The Bahamas, they also remain distinct communities.

While there is an idealized image of the United States as a nation of economic opportunity, this masks its position as a world leader in incarceration (Blumstein, 2011). It incarcerates around 698 people per 100,000 in the population compared to 379 per 
100,000 in The Bahamas (International Centre for Prison Studies, 2013). In the United States, incarceration rate increases have been driven by a socio-political position of being tough on crime facilitated primarily through the War on Drugs (Blumstein, 2011). Alexander (2012) has suggested that the War on Drugs has been used as a legal framework to maintain a racial caste in which men of colour are systematically incarcerated and stripped of their rights. Violence in the United States continues to gain world attention due to the killings of black males by police (Mejia, 2014). So, the United States is not presented as a panacea but rather as a country with its own set of interpersonal violence concerns.

Compared to the United States of America, less research has been undertaken on violence in The Bahamas. While a recent bibliography on violence in The Bahamas (Walker, Ballance, Pinder-Darling, Morris \& Bain, 2011) included relatively few research studies specific to The Bahamas, there is a slowly increasing body of such research (e.g. The College of The Bahamas, 2011). These studies have started to point to levels of violence both inside and outside of the home which may rival or exceed that in other countries (McPhedran, 2009; Hanna, 2011). For example, these studies indicate that Bahamian children are subject to physical discipline, threats and insults throughout childhood and that physical abuse can have detrimental effects on the development of children (Carroll, Fielding, Brennen, \& Hutcheson, 2011).

Nonetheless, a comparison of child abuse etc. between The Bahamas and the United States is difficult due to a lack of statistics from The Bahamas which match those from the United States (e.g., Sedlak et al., 2010). Statistics from UNICEF (2014) demonstrate not only the global importance of violence in the lives of children, but the violence directed towards children within the United States. Extreme maltreatment of children is a cause for concern in the United States as the country has a high death rate due to the mistreatment of children compared with other "rich" nations (UNICEF, 2003). Consequently, it is apparent that children in both The Bahamas and the United States are victims of abuse. While studies on violence towards children within The Bahamas, such as those of Carrol et al. (2011) are of interest per se, without a frame of reference, it is difficult to interpret the results.

The data reported here come from a larger study whose primary purpose was to examine attitudes and behaviours of college/university students towards animals and people in two communities in The Bahamas and the United States. In the absence of previous studies comparing violence in The Bahamas to violence in the United States, outside of homicides (Hanna, 2011) and rape (United Nations Office on Drugs and Crime, 2014), the purpose of this study is to examine violence among American and Bahamian college students. This paper provides information about these students' backgrounds and the levels and types of violence to which they were subjected as children which is required for investigating relationships between human and non-human animals (e.g., Humane Society of the United States, 2011). These relationships, highlighting cross-cultural aspects from this study, will be reported elsewhere.

\section{METHOD}

The study was conducted at two institutions of higher education offering university-level degree courses, one large university in the southwest United States and the other a smaller institution in The Bahamas. The study required undergraduate students to complete an online questionnaire of 233 questions regarding relationships in families as well as with animals. A major portion of 
the questionnaire was taken from one created for the study of childhood animal abuse and interpersonal violence (Flynn, 1999a). Information was obtained from respondents on demographics, the home and parents, actual or anticipated use of spanking of the respondent's children, frequency of spanking of respondents by parents, and resultant injuries, violence between parents, attitudes of respondents to interpersonal violence of married couples, use of violence by respondents and experiences of animal abuse. The questionnaire was originally devised in the context of the United States, and so it was pretested and critiqued by a class of Bahamian students to insure it was understandable cross-culturally.

Undergraduate college students were sampled to counter the common use of clinical/criminal populations when studying violent behaviour, especially against animals. In addition, it provided access to a large and potentially more diverse population from which to draw participants. The respective authors' Institutional Research Boards and Ethics Committees approved the study.

\section{Recruitment}

Students from an American university enrolled in undergraduate liberal arts classes were invited to participate through a posting on their class Blackboard ${ }^{\mathrm{TM}}$ site. A recruitment flyer briefly explained the nature of the research, including that they needed to be aged 18 or over to participate, and provided students with a link to a Qualtrics Online Survey. This included a cover letter explaining the process in more detail, including a lottery incentive of Amazon ${ }^{\mathrm{TM}}$ gift cards. In addition, students in the United States were awarded one point extra credit in their class for completing the survey. In The Bahamas, college students were invited to participate through e-mails and announcements in classes in the social sciences. A gift card was again offered in a lottery to encourage participation. Anonymity was maintained by including a separate link at the end of the survey to allow respondents to provide contact information if they wanted the extra credit and/or to enter the lottery. The questionnaire did not require students to answer any question, other than the consensual question.

Originally 830 students started the online questionnaire. After cleaning the data, and removing ineligible responses (e.g., some students were under 18 years of age) the final sample included 740 students. Not all these responses were complete, so this represents the maximum sample size. For clarity of presentation, the students attending the university in the United States of America will be called “American" students and those attending college in The Bahamas will be called "Bahamian" students, recognizing that these terms may not necessarily correspond with the citizenship of students or their parents.

\section{The questionnaire}

This paper focuses on a subset of the original 233 questions. We report on respondents' demographics, violence in the home, respondents' experiences of violence and their attitudes/feelings about using violence as parents. In recognition that family structures can be complex, when we refer to parents (mothers and fathers) in reality we mean "parental figures" to include those persons who would be expected to perform the role and function of fathers or mothers, irrespective of their formal relationship with their intimate partner or with the student.

Violence was assessed by a series of questions including the use of violence by one or both parents on students as well as violence between parents and abuse of animals by parents. To get an appreciation of the severity of the violence used, we asked questions about the consequences of the 
discipline received by respondents (e.g., did you ever suffer an injury as a result of being physically disciplined by parental figures etc.?). Students were also asked questions about their own violent behaviour such as abuse of animals, violence in their dating relationships as well as their tendency to have angry outbursts. Attitudes towards specific parenting issues were assessed by asking students if they might approve of a husband and wife slapping each other, and whether they intended to spank or practised spanking their own children.

The results were analyzed using appropriate procedures in the IBM SPSS Statistics programme. Due to the fact that most of the questions resulted in nominal or interval data, non-parametric statistical procedures were used, except in the case of age data.

\section{RESULTS}

\section{The Participants}

The sample included 740 students with 559 (75.5\%) residing in the United States at the time of the study and 180 (24.3\%) residing in The Bahamas. The majority of students were female (82.9\% of 737); the mean age was 21 years $(M d n=21$; mode $=21$; range 18-49) and $73.9 \%$ (of 739 students) were juniors/seniors in their academic programmes. Approximately half (49.9\%) of students (738) gave their primary identity as Caucasian; $16.4 \%$ identified themselves as Afro-Caribbean; $\quad 12.3 \%$ as Hispanic (Chicano/Mexican, Puerto Rican, Other Hispanic/Latino/a) and $7.3 \%$ as African American.

With regard to American and Bahamian students, there were proportionately more females in the sample of American students. 85.1\% of 558 American respondents were female as opposed to $76.0 \%$ of 179 Bahamian students (Fisher's exact test, $n=769, p=$ .009). The mean ages of the two groups of students were similar $(t=-.726, n=683, p=$
.558). As might be expected, the ethnicity of the Bahamian students was dominated by African-American or Afro-Caribbean (82.8\%) with $1.1 \%$ Caucasian as opposed to $4.7 \%$ African-American and 65.6\% Caucasian in the American sample.

The homes of both American and Bahamian students were equally likely to include siblings (90.7\% of 738). The household composition, in terms of percentages with either/or/both male/female parental figures present etc., in which respondents were brought up during their high school years, was broadly similar. When considering household composition in terms of having one or two parents in the home, this was similar for students both in The Bahamas and the United States (56.2\% in the United States and $57.2 \%$ in The Bahamas). Similar percentages of students $(71.3 \%$ of 558 Americans and $65.9 \%$ of 179 Bahamians) had parents who were married.

The educational attainment of students' parents was different between the two countries, with those in The Bahamas less likely to have an education beyond high school. This was found for both fathers, $\chi^{2}(7$, $N=702)=31.6, p<.001$, and mothers, $\chi^{2}(7$, $N=723)=25.2, p=.001$. Of 540 American fathers, $69.2 \%$ were educated beyond high school, as opposed to $54.9 \%$ of 162 Bahamian fathers. In the case of mothers, $70.9 \%$ of 548 American mothers were educated beyond high school compared to $56.6 \%$ of 175 in The Bahamas.

A similar percentage of students in both countries had grown up with pets (94.1\%). American households were more likely than Bahamian households to own firearms; 41.9\% (of 532) of American students lived in homes with guns when they were growing up, compared to 22.1\% (of 163) of Bahamian students (Fisher's exact test, $n=695, p<$ .001). 


\section{Parental Figure Violence in Students' Homes}

Parent-to-parent violence. The occurrence of parent-to-parent violence, defined as hitting or throwing something at the other, varied according to the sex of the respondent and the country in which respondents lived. There was no significant difference in the use of violence on mothers by fathers in either country: $19.1 \%$ of American students and 20.5\% of Bahamian students had fathers who had hit their mothers (Fisher's exact test, $n=$ $661, p=.385$ ). However, there was a country difference between violence by mothers or fathers reported by female respondents, but not by male respondents. Bahamian female students reported more mother-on-father violence than American female students with
$27.7 \%$ of Bahamian students reporting this compared with $18.4 \%$ of American students (Fisher's exact test, $n=547, p=.035$ ).

The frequency of use of violence by parents between each other was linked with the educational attainment of the male parental figure is displayed in Table 1 for both countries. Lower educational level was significantly related to increased frequency of violence toward the mother figure. While this association was more pronounced in the United States, a similar pattern was also found in The Bahamas. The smaller sample size of the Bahamian group may be responsible for the trend not being formally significant.

Table 1

Correlation between level of education and frequency of violence between parental figures (Kendall's tau $r_{T}$ )

\begin{tabular}{|c|c|c|c|}
\hline & Level of education & of father figure & of mother figure \\
\hline United States & Frequency with which father figure hit mother figure & $-.120^{\star \star}$ & \\
\hline The Bahamas & Frequency with which father figure hit mother figure & $-.163^{*}$ & \\
\hline United States & Frequency with which mother figure hit father figure & & $-.178^{\star \star}$ \\
\hline The Bahamas & Frequency with which mother figure hit father figure & & -.123 \\
\hline
\end{tabular}

* Correlation is significant at the .05 level (2-tailed).

${ }^{*}$ Correlation is significant at the .01 level (2-tailed). No associations were found between the presence of a firearm in homes and the frequency of violence between parents in homes $(p>.05)$.

Parental violence towards students. Before becoming teenagers, students in both countries were spanked with equal frequency by their fathers $\left(\chi^{2}(6, N=694)=6.99, p=\right.$ .322). However, Bahamian students were spanked with greater frequency by their mothers than American students $\left(\chi^{2}(6, \mathrm{~N}\right.$ =728) $=104.8, p=<.001)$. As students became teenagers, mothers and fathers in The Bahamas were more likely than their American counterparts to spank their children. Associated with this, mothers in
The Bahamas were more likely to have attacked (attack meaning to kick, punch, choke or use a weapon to beat up the child) the student as a pre-teen than American mothers. However, this pattern of behaviour did not persist into the teenage years, as shown in Table 2. Mothers in The Bahamas were generally more likely to commit acts of violence on children than American mothers. It should also be noted, that for some aspects of violence, the responses depended upon the student's sex. 
Table 2

Percentage of female/male students suffering selected violent acts

\begin{tabular}{llcccc}
\hline Sex & \multicolumn{1}{c}{ Violent act } & Victimizer & United States & The Bahamas & Fisher's exact test $p$ \\
\hline Both sexes & \multirow{2}{*}{ As pre-teenagers, } & Father & 61.8 & 69.8 & .076 \\
Males & ever spanked by: & Mother & 76.8 & 90.5 & .087 \\
Females & & Mother & 67.9 & 95.5 & $<.001$ \\
\hline Males & As teenagers ever & Father & 27.5 & 43.6 & .062 \\
Females & Father & 19.0 & 34.4 & $<.001$ \\
Both sexes & spanked by: & Mother & 29.9 & 69.5 & $<.001$ \\
\hline Both sexes & \multirow{2}{*}{ As pre-teenagers, } & Father & 2.7 & 3.6 & .338 \\
Males & ever attacked & Mother & 6.1 & 7.0 & .562 \\
Females & & Mother & 3.4 & 9.2 & .009 \\
\hline Both sexes & \multirow{2}{*}{ As teenagers, ever } & Father & 4.5 & 2.4 & .358 \\
Males & attacked & Mother & 6.3 & 4.7 & $>.99$ \\
Females & & Mother & 4.4 & 7.4 & .067 \\
\hline Both sexes & Ever injured as a result of physical discipline by parents & 7.4 & 10.1 & .268 \\
\hline Both sexes & Ever needed treatment by a doctor for these injuries & 2.0 & 0.5 & .401 \\
\hline "Atack" mean & kick, punch, choke & & \\
\hline
\end{tabular}

"Attack" means to kick, punch, choke or use a weapon to beat up the child.

Overall, mothers were responsible for more violence than fathers towards their children, as illustrated in Table 3. In homes with both parents, mothers were responsible for more spanking than fathers at both the pre- and post-teen stages of the respondent. Parents in The Bahamas made more use of physical punishment than American parents.

Table 3

Frequency of use of physical punishment in homes with both parents present at different stages of respondents' life

\begin{tabular}{|c|c|c|c|c|c|c|c|c|}
\hline \multirow{3}{*}{ Wilcoxon signed ranks } & \multicolumn{4}{|c|}{ Pre- teen } & \multicolumn{4}{|c|}{ Teenager } \\
\hline & \multicolumn{2}{|c|}{ United States } & \multicolumn{2}{|c|}{ The Bahamas } & \multicolumn{2}{|c|}{ United States } & \multicolumn{2}{|c|}{ The Bahamas } \\
\hline & \multicolumn{8}{|c|}{ Mother using physical violence more frequently than father } \\
\hline z-score & \multicolumn{2}{|c|}{2.25} & \multicolumn{2}{|c|}{7.62} & \multicolumn{2}{|c|}{2.92} & \multicolumn{2}{|c|}{7.09} \\
\hline \multirow[t]{4}{*}{$p$} & \multicolumn{2}{|c|}{.024} & \multicolumn{2}{|c|}{$<.001$} & \multicolumn{2}{|c|}{.003} & \multicolumn{2}{|c|}{$<.001$} \\
\hline & \multicolumn{8}{|c|}{ Frequency (no. of times) } \\
\hline & \multicolumn{4}{|c|}{ Pre-teen } & \multicolumn{4}{|c|}{ Teenager } \\
\hline & \multicolumn{2}{|c|}{ United States } & \multicolumn{2}{|c|}{ The Bahamas } & \multicolumn{2}{|c|}{ United States } & \multicolumn{2}{|c|}{ The Bahamas } \\
\hline Percentile group & Mother & Father & Mother & Father & Mother & Father & Mother & Father \\
\hline $25 \%$ & 0 & 0 & $3-5$ & 0 & 0 & 0 & 0 & 0 \\
\hline $50 \%$ & 2 & 2 & $6-10$ & 2 & 0 & 0 & 2 & 0 \\
\hline $75 \%$ & $6-10$ & $3-5$ & $>20$ & $6-10$ & 2 & 1 & $3-5$ & 2 \\
\hline$n$ & 553 & 532 & 175 & 162 & 551 & 518 & 174 & 162 \\
\hline
\end{tabular}

The frequency of spanking used by parents increased when respondents had siblings in the household in both American and Bahamian homes. For American students 
Mann-Whitney $U$ tests indicated an increase in the frequency in the spanking for respondents with siblings, as opposed to no siblings. This was significant in the case of mothers spanking the respondent as a preteen $(U=10274.5, p=.002)$ and for fathers spanking the respondent as a teenager ( $U=$ 10939.5, $p=.032$ ). A similar result was also found in the Bahamian group $(U=597.0, p=$ .021) for mothers spanking the respondent as a pre-teen and for fathers spanking the respondent as a teenager $(U=336.0, p=$ $.048)$.

In the American group, the level of education of father was correlated with the number of times respondents were hit as teenagers $\left(r_{\tau}=\right.$ .076, $p=.032, n=545)$. The level of education of mothers was correlated with the number of times respondents here hit, both when a pre-teenager and when a teenager $\left(r_{\tau}\right.$ $=-.136, p<.001, n=549$ and $r_{\tau}=-.162, p<$ $.001, n=553$ respectively). No corresponding associations were found in the Bahamian group for either fathers or mothers. However, it should be noted that the number of Bahamian respondents might have been too small to detect a relationship.

The frequency with which students were spanked as children was associated with the intention of students to spank their own children. For American students, the frequency with which mothers spanked them, as preteens and teenagers, was associated with students planning to spank their own children $(U=14898, p<.001$, and $U=$ 19615.5, $p<.001$ respectively). The frequency of fathers spanking students as preteens was also associated with students' intention to spank their own children ( $U=$ 16081.5, $p<.001)$. In the Bahamian group, the association was only noted for mothers spanking students, both as preteens $(U=564$, $p=.026)$ and as teenagers $(U=511.5, p=$ $.010)$.
Violence against animals. Another form of violence found in homes and associated with parent-to-parent abuse as well as the use of physical discipline of children (Flynn, 1999b) is abuse of animals by family members. This can be in the form of the parent or other family member (e.g., sibling) actually abusing the animal himself or the child abusing an animal. While the occurrence of animal abuse in general is fairly low it is associated with other forms of family violence. In this study 104 students witnessed someone kill an animal for reasons other than food, hunting or to help the animal. Six students (2 American, 4 Bahamians) reported they had witnessed their mother killing an animal for reasons other than food, hunting or to help the animal. Thirteen had witnessed their father doing the same (7 Americans, 6 Bahamians); eight had seen a sibling kill an animal (6 Americans, 2 Bahamians); and 25 (18 Americans; 7 Bahamians) reported having seen another relative kill an animal for reasons other than those mentioned above.

Four students indicated that someone had tried to control them by threatening to use or using violence on an animal; three of these students lived in the United States. The victimizers were father/stepfather: 1; mother/stepmother: 2; siblings: 3; and other relatives: 2 .

\section{Other Violence in the Lives of Students}

Students were asked about the use of selected violent behaviours in their interactions with their dating partners, as illustrated in Table 4. The personal experiences of violence by students were generally similar in both countries. One exception was in the case of students being hit by an object by someone they were dating. Females in the United States were more likely to have suffered from this violence than females in The Bahamas, but not males. 
Table 4

Percentage of students experiencing interpersonal violence by country and gender between countries

\begin{tabular}{|c|c|c|c|c|}
\hline Action & & U.S. & Bahamas & Fisher $p$ \\
\hline $\begin{array}{l}\text { Have you ever kicked, punched, bitten, choked, beaten up, or } \\
\text { attacked with a weapon someone you were dating }\end{array}$ & Both sexes & 5.8 & 8.6 & 0.22 \\
\hline Have you ever hit or thrown something at someone you were dating? & Both sexes & 30.2 & 26.1 & 0.34 \\
\hline $\begin{array}{l}\text { Have you ever tried to force a dating partner to have sexual relations } \\
\text { with you by using physical force }\end{array}$ & Both sexes & 0.7 & 1.7 & 0.37 \\
\hline $\begin{array}{l}\text { Have you ever forced a dating partner to have sexual relations with } \\
\text { you by using physical force }\end{array}$ & Both sexes & 0.4 & 1.1 & 0.24 \\
\hline \multirow{2}{*}{$\begin{array}{l}\text { Have you ever been hit or had something thrown at you by someone } \\
\text { you were dating? }\end{array}$} & Male & 24.4 & 14.6 & 0.25 \\
\hline & Female & 25.8 & 16.8 & 0.04 \\
\hline $\begin{array}{l}\text { Have you ever been kicked, punched, bitten, choked, beaten up, or } \\
\text { attacked with a weapon by someone you were dating? }\end{array}$ & Both sexes & 11.3 & 7.5 & 0.16 \\
\hline $\begin{array}{l}\text { Has a dating partner ever tried to force you to have sexual relations by } \\
\text { using physical force }\end{array}$ & Both sexes & 11.5 & 12.7 & 0.67 \\
\hline $\begin{array}{l}\text { Has a dating partner ever forced you to have sexual relations by using } \\
\text { physical force, such as holding down, hitting or threatening to hit }\end{array}$ & Both sexes & 7.0 & 5.7 & 0.73 \\
\hline
\end{tabular}

One difference, however, was with the American students where increased frequency of parental spanking of students when teenagers was associated with students attacking (with a weapon etc.) their dating partner (father spanking $U=5671.5, p=$ .004; mother spanking $U=5697, p<.001$ ). Similarly in the American group only, frequency of spanking was associated with students who had thrown something at their dating partner (mother spanking student as a pre-teen, $\mathrm{U}=28053, p=.020$, father spanking the student as a teenager $U=25477$, $p=.034$ and mother spanking the student as teenager, $U=24819, p<.001)$. No equivalent associations were found in the Bahamian group.

Overall, differences between the responses of males and females were only found for hitting a dating partner and having been forced to have sexual relations with a dating partner, and not for the other actions listed in Table 4. Males were less likely to have hit a dating partner than females (8.0\% of 125 males; $33.7 \%$ of 606 females, Fisher's exact test, $n=731, p<.001)$. However, females were more likely than males to have been coerced to have sexual relations by physical force with a dating partner (13.6\% of 605 females compared with $3.3 \%$ of 123 males, Fisher's exact test, $n=728, p=0.001$ ).

Interpersonal violence often co-occurs with animal abuse. Eight students (0.8\% of 124 males and $1.2 \%$ of 597 females) in both countries had killed a pet other than for humane reasons. However, $10.6 \%$ of 123 males and $1.3 \%$ of 599 females had killed a stray or wild animal (other than for food), demonstrating gender-associated levels of violence (Fisher's exact test, $n=722, p<$ .001). This gender difference persisted across both groups of students. Hurting or torturing an animal was more common in the Bahamian group (9.9\%) compared to $1.7 \%$ in the American group (Fisher's exact test, $n=$ 644, $p<.001)$.

\section{Attitudes towards Parental Behaviours}

Students from the two communities had different attitudes towards violence between husbands and wives (see Table 5). Bahamian 
females showed greater approval of slapping between husbands and wives than their American counterparts. However, American and Bahamian male students had similar attitudes (disapproval) towards wives hitting their husbands, but disagreed about husbands hitting their wives, with Bahamians expressing more approval. What may be considered the classical stereotype of males being the achiever outside the home was disapproved of to an almost equal extent by both groups of students.

Table 5

Student attitudes about parental gender roles by country United States (US) and The Bahamas (BS) (percentages)

\begin{tabular}{|c|c|c|c|c|c|c|c|c|c|c|c|}
\hline \multirow[b]{2}{*}{ Attitude: } & & \multicolumn{4}{|c|}{ Male students } & \multicolumn{6}{|c|}{ Female students } \\
\hline & & $\begin{array}{l}\text { Strongly } \\
\text { Disagree }\end{array}$ & Disagree & Agree & $\begin{array}{c}\text { Strongly } \\
\text { Agree }\end{array}$ & $x^{2} p$ & $\begin{array}{l}\text { Strongly } \\
\text { Disagree }\end{array}$ & Disagree & Agree & $\begin{array}{c}\text { Strongly } \\
\text { Agree }\end{array}$ & $X^{2} p$ \\
\hline \multirow{2}{*}{$\begin{array}{l}\text { I can imagine a } \\
\text { situation in which I } \\
\text { would approve of a } \\
\text { wife slapping her } \\
\text { husband. }\end{array}$} & US & 32.5 & 21.7 & 41 & 4.8 & \multirow[b]{2}{*}{.564} & 42.9 & 24.5 & 29.4 & 3.2 & \multirow[b]{2}{*}{.024} \\
\hline & BS & 42.9 & 23.8 & 31 & 2.4 & & 35.3 & 27.2 & 28.7 & 8.8 & \\
\hline \multirow{2}{*}{$\begin{array}{l}\text { I can imagine a } \\
\text { situation in which I } \\
\text { would approve of a } \\
\text { husband slapping } \\
\text { his wife. }\end{array}$} & US & 77.1 & 19.3 & 3.6 & 0.0 & \multirow[b]{2}{*}{.036} & 75.2 & 21.1 & 3.6 & 0.2 & \multirow[b]{2}{*}{.002} \\
\hline & BS & 58.1 & 27.9 & 14 & 0.0 & & 64.0 & 26.5 & 6.6 & 2.9 & \\
\hline \multirow{2}{*}{$\begin{array}{l}\text { It is much better if } \\
\text { the man is the } \\
\text { achiever outside } \\
\text { the home }\end{array}$} & US & 24.1 & 43.4 & 24.1 & 8.4 & \multirow{2}{*}{.822} & 43.0 & 39.0 & 15.6 & 2.3 & \multirow{2}{*}{.175} \\
\hline & BS & 20.9 & 46.5 & 27.9 & 4.7 & & 33.1 & 43.4 & 19.9 & 3.7 & \\
\hline
\end{tabular}

Students' attitudes towards gender roles were correlated with frequency of spanking by American students but not by Bahamian students as illustrated in Table 6. Students from The Bahamas indicated that they would be more likely to spank their children than American students: 63.3\% of Bahamian students who had children spanked their children compared to $17.5 \%$ of American students (Fisher's exact test, $n=127, p<$ .001). Most (90.1\%) Bahamian students intended to spank their children, if they had any, compared to $46.0 \%$ of American students (Fisher's exact test, $p<.001, n=$ 585). This intent or actual use of spanking, was associated with the students' own experience of spanking in their childhood in Table 7. Possibly due to the ubiquitous use of spanking in The Bahamas, the association between the spanking behaviour of one generation being passed on to the next does not always emerge as statistically significant as in the case of the American students. 
Table 6

Correlations (Kendall's tau $r_{T}$ ) between frequency of spanking of respondent \& attitudes towards gender roles by country

$\begin{array}{ccc}\begin{array}{c}\text { I could approve of } \\ \text { a wife slapping } \\ \text { her husband. }\end{array} & \begin{array}{c}\text { I could approve of } \\ \text { a husband }\end{array} & \begin{array}{c}\text { The man should be } \\ \text { the achiever }\end{array} \\ & \text { slapping his wife. } & \text { outside the home }\end{array}$

\begin{tabular}{|c|c|c|c|c|}
\hline \multirow{7}{*}{ 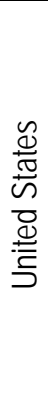 } & I could approve of a wife slapping her husband. & 1 & & \\
\hline & I could approve of a husband slapping his wife. & $.378^{\star *}$ & 1 & \\
\hline & The man should be the achiever outside the home & $.120 * \star$ & 0.033 & 1 \\
\hline & As a pre-teen, frequency of spanking by mother & 0.081 & $.089^{*}$ & 0.05 \\
\hline & As a pre-teen, frequency of spanking by father & 0.075 & $.104^{*}$ & 0.006 \\
\hline & As a teenager, frequency of spanking by mother & $.112^{*}$ & $.137^{\star *}$ & 0.02 \\
\hline & As a teenager, frequency of spanking by father & $.086^{*}$ & $.125^{\star *}$ & -0.037 \\
\hline \multirow{7}{*}{ 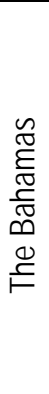 } & I could approve of a wife slapping her husband. & 1 & & \\
\hline & I could approve of a husband slapping his wife. & $.533^{\star \star}$ & 1 & \\
\hline & The man should be the achiever outside the home & 0.098 & 0.111 & 1 \\
\hline & As a pre-teen, frequency of spanking by mother & -0.028 & -0.02 & -0.055 \\
\hline & As a pre-teen, frequency of spanking by father & -0.046 & 0.067 & -0.057 \\
\hline & As a teenager, frequency of spanking by mother & -0.030 & 0.008 & 0.029 \\
\hline & As a teenager, frequency of spanking by father & 0.055 & 0.065 & 0.126 \\
\hline
\end{tabular}

** Correlation is significant at the 0.01 level (2-tailed).

${ }^{*}$ Correlation is significant at the 0.05 level (2-tailed).

Table 7

Attitudes of students towards spanking their children, by country, United States (US) and The Bahamas (BS), being spanked/hit as a child (percentage who do/would spank)

Ever slapped by father, when a preteen Ever slapped by mother, when a preteen

\begin{tabular}{|c|c|c|c|c|c|c|c|}
\hline & & No & Yes & $p$ & No & Yes & $p$ \\
\hline & US & 30.4 & 55.6 & $<0.001$ & 22.0 & 56.4 & $<0.001$ \\
\hline \multirow[t]{2}{*}{ If I have children, I will spank them } & BS & 82.1 & 93.3 & 0.062 & 50.0 & 92.4 & 0.004 \\
\hline & US & 7.1 & 25.0 & 0.028 & 9.4 & 21.9 & 0.16 \\
\hline \multirow[t]{3}{*}{ I have children and I have spanked or hit them } & BS & 44.4 & 68.8 & 0.4 & 50.0 & 61.5 & $>0.99$ \\
\hline & & \multicolumn{3}{|c|}{ Ever slapped by father, when a teen } & \multicolumn{3}{|c|}{ Ever slapped by mother, when a teen } \\
\hline & & No & Yes & $p$ & No & Yes & $p$ \\
\hline \multirow{3}{*}{ If I have children, I will spank them } & US & 43.6 & 53.5 & 0.12 & 40.4 & 60.0 & $<0.001$ \\
\hline & BS & 88.8 & 91.5 & 0.77 & 78.0 & 94.8 & 0.005 \\
\hline & US & 18.7 & 11.1 & 0.73 & 16.9 & 19.4 & 0.79 \\
\hline I have children and I have spanked or hit them & BS & 43.8 & 88.9 & 0.040 & 42.9 & 65.0 & 0.39 \\
\hline
\end{tabular}

Fisher's exact test $p$ value. 


\section{Student Anger Associated with Violence in the Home}

Anger is an important factor in violence. Students were asked about frequency of angry outbursts (on a scale, Never $=1$, to Always $=6$ ) and this was correlated with the frequency of other violence to which they had either been subjected or might have observed while growing up (Table 8). In both student communities, violence in the home was linked with more frequent angry outbursts in the students.

Table 8

Correlations (Kendall's' tau $r_{T}$ ) of frequency of violence acts

\begin{tabular}{|c|c|c|c|c|c|c|c|}
\hline & $\begin{array}{l}\text { Student } \\
\text { has angry } \\
\text { outbursts. }\end{array}$ & $\begin{array}{l}\text { Preteen, } \\
\text { spanked by } \\
\text { father } \\
\text { figure }\end{array}$ & $\begin{array}{l}\text { Preteen, } \\
\text { spanked by } \\
\text { mother } \\
\text { figure }\end{array}$ & $\begin{array}{l}\text { As teenager, } \\
\text { spanked by } \\
\text { father figure }\end{array}$ & $\begin{array}{l}\text { As teenager, } \\
\text { spanked by } \\
\text { mother } \\
\text { figure }\end{array}$ & $\begin{array}{l}\text { Father figure } \\
\text { hit mother } \\
\text { figure }\end{array}$ & $\begin{array}{l}\text { Mother } \\
\text { figure hit } \\
\text { father } \\
\text { figure }\end{array}$ \\
\hline \multicolumn{8}{|l|}{ United States } \\
\hline $\begin{array}{l}\text { Student has angry } \\
\text { outbursts. }\end{array}$ & 1.00 & & & & & & \\
\hline $\begin{array}{l}\text { Preteen, spanked by } \\
\text { father figure }\end{array}$ & 0.03 & 1.00 & & & & & \\
\hline $\begin{array}{l}\text { Preteen, spanked by } \\
\text { mother figure }\end{array}$ & $.07 *$ & $.35^{\star \star}$ & 1.00 & & & & \\
\hline $\begin{array}{l}\text { As teenager, spanked } \\
\text { by father figure }\end{array}$ & $.13^{\star \star}$ & $.46^{\star \star}$ & $.22^{\star \star}$ & 1.00 & & & \\
\hline $\begin{array}{l}\text { As teenager, spanked } \\
\text { by mother figure }\end{array}$ & $.12^{\star \star}$ & $.15^{\star \star}$ & $.41^{\star \star}$ & $.40^{\star \star}$ & 1.00 & & \\
\hline $\begin{array}{l}\text { Father figure hit } \\
\text { mother figure }\end{array}$ & $.11^{* *}$ & $.19^{\star \star}$ & $.14^{\star *}$ & $.26^{\star *}$ & $.16^{\star \star}$ & 1.00 & \\
\hline $\begin{array}{l}\text { Mother figure hit } \\
\text { father figure }\end{array}$ & 0.04 & $.08^{\star}$ & $.22^{\star \star}$ & $.14^{\star \star}$ & $.29 * \star$ & $.53^{\star \star}$ & 1.00 \\
\hline \multicolumn{8}{|l|}{ The Bahamas } \\
\hline $\begin{array}{l}\text { Student has angry } \\
\text { outbursts. }\end{array}$ & 1.00 & & & & & & \\
\hline $\begin{array}{l}\text { Preteen, spanked by } \\
\text { father figure }\end{array}$ & -0.02 & 1.00 & & & & & \\
\hline $\begin{array}{l}\text { Preteen, spanked by } \\
\text { mother figure }\end{array}$ & 0.10 & $.17^{\star *}$ & 1.00 & & & & \\
\hline $\begin{array}{l}\text { As teenager, spanked } \\
\text { by father figure }\end{array}$ & 0.09 & $.46^{\star \star}$ & $.18^{\star \star}$ & 1.00 & & & \\
\hline $\begin{array}{l}\text { As teenager, spanked } \\
\text { by mother figure }\end{array}$ & $.13^{\star}$ & $.20^{\star \star}$ & $.37^{\star \star}$ & $.37^{\star \star}$ & 1.00 & & \\
\hline $\begin{array}{l}\text { Father figure hit } \\
\text { mother figure }\end{array}$ & $.20^{*}$ & 0.11 & 0.14 & $.20^{\star \star}$ & $.16^{\star}$ & 1.00 & \\
\hline $\begin{array}{l}\text { Mother figure hit } \\
\text { father figure }\end{array}$ & $.17^{\star}$ & 0.04 & 0.13 & 0.06 & 0.11 & $.41^{\star \star}$ & 1.00 \\
\hline
\end{tabular}

** Correlation is significant at the 0.01 level (2-tailed).

${ }^{*}$ Correlation is significant at the 0.05 level (2-tailed).

For both student groups, the frequency of angry outbursts was related to killing a pet ( $U$ $=1732, p=.048)$, but not with harming a stray animal $(U=6199.5, p=.14)$. Similarly, frequency of anger was associated with violence (hitting etc.) directed by the student towards a dating partner (overall, $U=44862$, $p=.002$, American students, $U=27336, p=$ 
.008, Bahamian students, $U=2065.5, p=$ .064). More extreme violence towards a date such as attacking with a weapon was also related with frequency of anger outbursts (American students, $U=6626, p=.05$ : Bahamian group, $U=671, p=.023$ ). Despite the fact that only a total of eight students had forced their partner to have sexual relations using physical force, this action still tended to be linked with frequency of anger outbursts ( $U=1577.5, p=.084)$.

\section{DISCUSSION}

The results from this study allow us to compare violence in the lives of college students from the United States of America and a Caribbean country, namely The Bahamas. It appears to be the first study not limited to official statistics to do so in these two contrasting communities. The comparison of students at colleges from both the United States of America and The Bahamas allows us to start to put into perspective the claims by McEwen (2010) that The Bahamas suffers from high levels of violence in its homes.

We are aware, however, of the limitations of the study. For example, the sample was selfselected and this may have introduced bias into the results. However, as similar incentives were used to recruit respondents, this may have standardized the bias in each group. There is also a large disparity between the numbers of participants from each institution. This was expected given the size of each institution but this may mean some statistical differences found only in the American sample may be a result of the smaller sample size from The Bahamas, rather than the differences not being consistent across both student groups. Additionally since the target population was college students, the results of this study should not be considered to necessarily apply at the national level.
While the students from The Bahamas represent a fairly homogenous group, those from the United States were more diverse. Despite the ethnic differences between the two groups of students, the composition of residential parental figures in student homes was generally similar, and so it could be expected that this might provide a similar learning experience as to how adults interact with each other. However, notwithstanding this similarity in household composition, the educational attainment of fathers and mothers was different in the United States and The Bahamas. This exposure to education influences problem-solving skills (Gokhale, 1995) and this may account, in part, for differences is the use of spanking between the Bahamian and American parents. Given the linkage between household size and domestic violence (e.g., Flake \& Forste, 2006) and the economic pressures which can exist in Bahamian homes it can be anticipated that these factors can increase the risk of violence in homes (Hahnlen, Rosado, Capozzi \& Hamon, 1997). These findings support the importance of education in helping to reduce the level of violence in society, and that the value of education goes beyond skills which are valued by the workplace.

It is clear that Bahamian students in this study were subjected to more violence in their homes than American students. The ubiquitous nature of violence in Bahamian homes, combined with the smaller sample size may have prevented some other spanking-related associations noted in the American group from being detected in the Bahamian sample. Carroll et al. (2011) and Brennen et al. (2010) have demonstrated that corporal punishment is common in Bahamian households, a finding repeated here. Indeed, as reported by D'Avanzo (2008) this is a cultural norm in West Indian communities. The association between the parental use of spanking and its long-term effects were 
implied by the responses from both groups of students. This included intergenerational violence, through the intention of students to spank their own children, and the use of violence towards their dating partners. Negative parenting skills are thought to contribute to violence in Jamaican society (Smith \& Mosby, 2003) and the findings of this study support the linking of the actions of parents with the behaviour of their adult children. This is a cause for concern.

Despite the cultural differences of respondents within this study, intergenerational violence was found which manifested itself in several violent behaviours of students. The frequency of being spanked as children was linked with increased frequency of anger outbursts as young adults, and this in turn was linked with violent behaviour of students towards people and animals. Consequently, it is possible to conjecture that parental actions towards children, as exhibited by frequent spanking, contributes to the rearing of students who are liable to more outbursts of temper and violent behaviour. Clarey, Hokoda, and Ulloa (2010) studied anger and violence towards dating partners in Mexico finding that it can be influenced by the violent experiences of students, including parental violence. While appreciation of intergenerational violence is not new, as Kim notes "is not at all deterministic, and there is considerable individual variation in individuals' responses to early experiences with violence" (2012, p. 395). This caveat is important as it allows for the possibility that violence can be transferred to future generations. Consequently, there is a need for interventions which address anger control for both parents and children. While the reasons for there being a higher occurrence of mother-on-father violence reported in the Bahamian group compared to the American group cannot be provided by this study, the results suggest that Bahamian students may be more likely to learn that violence is a normal part of adult interpersonal relationships than American students. It is also suggested that public figures (e.g., from politicians to pop stars) be positive role models, rather than ones who glorify abuse and violence (e.g., Missick, 2014; Eminem, 2010). Public glorification of interpersonal violence implies violence is a behaviour that should be imitated and so perpetuated.

Bahamian and American students had different attitudes towards gender roles with Bahamian students being more supportive of the traditional stereotype of the man as the breadwinner and by implication the head of the household, a view expressed by Bahamian politicians (Cartwright-Rolle, 2014), even though this contradicts the current norm of both parents having a job (Nicolls et al, 2014). Frequency of spanking was linked with student attitudes towards gender roles in the American group but not in the Bahamian group. Further study would be required to investigate this in detail. While the findings in the American group are consistent with the propagation of intergenerational violence, any similar connection in The Bahamian group is probably masked by the overall common use of spanking, which could hide such a relationship.

Despite the increased violence to which Bahamian students were exposed compared to American students, Bahamian students were no more violent in their own actions than American students. Kim (2012) suggests that any mechanism which may link exposure to violence in childhood can be and is modified in ways not captured in this study and so may be associated "personal and cultural factors” (p. 395) or a cultural "construction of reality and meanings attached to violence” (p. 403). This indicates a need for further research to identify factors 
which intervene to alter the linkage between being a victim as a child and a victimizer as an adult. It is of interest to note that the only significant difference between the Bahamian and American students in Table 4 indicated a higher level of violence towards female students in the United States than the Bahamian group. We need to be aware that there could have been cultural differences in the self-reporting of violence, especially since (a) overall respondents were disproportionately female and (b) American respondents included proportionately more females than the Bahamian group. So for example there may be greater denial, or appreciation of these actions in the Bahamian group than in the American group. Brennen et al (2010) showed that residents of The Bahamas tend to consider what might be viewed as grievous bodily harm as physical abuse. Henning, Jones and Holdford (2005) noted differences in denial concerning domestic violence between males and females, so we cannot rule out the possibility of socially desirable responding, despite the confidential manner in which the data were collected. If denial is an issue, then students may need to be educated about violence as proposed by Paquette (2004).

Fielding (2008) has demonstrated differences in the attitudes towards animals in the United States and The Bahamas but the link between animal cruelty and domestic violence in The Bahamas (Fielding \& Plumridge, 2010) is consistent with that noted elsewhere
(Ascione, 2008). As might be expected, relatively few respondents had harmed animals, but consistent with their exposure to violence at home, Bahamian students were more likely than American students to harm or torture an animal. The harm inflicted upon animals by students appeared to be associated with the frequency of parental spanking of their children. This is consistent with other research that suggests animal abuse is a red flag for family violence. The study also showed that family members use harming animals to control people. These findings are consistent with those in other studies (Ascione, 2008).

This study allows us to compare and contrast violence and attitudes towards violence in the lives of college/university students, but does not allow us to explain why these attitudes/actions arise. While it is apparent that parental behaviours have important impacts on the behaviour of children, everincreasing levels of violence towards children would not appear to be simply associated with ever-increasing levels of violence in children as young adults. Although the mechanism linking childhood experience with violence may be complex, it is clear that programmes that target the reduction of corporal punishment of children are potentially important in reducing violence when those children become adults. It also again raises the question of whether or not corporal punishment of children should be permitted (e.g., Oas, 2010; Lenta, 2012).

\section{REFERENCES}

2007 daylight saving time change FAQ.

Retrieved from https://web.archive.org/

web/20110713120534/http://ftp.redhat.co

m/redhat/dst2007/README/DSTFAQ200

7_final.pdf

Alexander, M. (2012). The new Jim Crow:

Mass incarceration in the age of

colorblindness. New York, NY: The New

Press.

Ascione, F. R. (Ed.). (2008). The

international handbook on animal abuse

and cruelty: Theory, research, and

application. West Lafayette, IN: Purdue

University Press. 
Blumstein, A. (2011). Bringing down the U.S. prison population. The Prison Journal, 91(3), 12S-26S. http://dx.doi.org/10.1177/ 0032885511415218

Brennen, S., Fielding, W. J., Carroll, M. C., McCants Miller, J. C., Adderley, L., \& Thompson, M. A. (2010). A preliminary investigation of the prevalence of corporal punishment of children and selected cooccurring behaviours in households on New Providence, The Bahamas. The International Journal of Bahamian Studies, 16, 1-18. http://dx.doi.org/10.15362/ijbs.v16i0.121

Cartwright-Rolle, T. (2014, August 1). Miller concerned about constitutional amendment bill. The Nassau Guardian. Retrieved from http://www.thenassauguardian.com/news/4 9241-miller-concerned-aboutconstitutional-amendment-bill

Carroll, M., Fielding, W. J., Brennen, S. \& Hutcheson, S. (2011, November). Rearing violence in Bahamian homes. Paper presented at the Violence Symposium, The College of the Bahamas, Nassau, Bahamas. Retrieved from http://ufdc.ufl.edu/AA00012380/00001

Child Welfare Information Gateway. (2013). Long-term consequences of child abuse and neglect. Washington, DC: U.S. Department of Health and Human Services, Children's Bureau. Retrieved from https://www.childwelfare.gov/ pubPDFs/long_term_consequences.pdf

Clarey, A., Hokoda, A., \& Ulloa, E. C. (2010). Anger control and acceptance of violence as mediators in the relationship between exposure to interparental conflict and dating violence perpetration in Mexican adolescents. Journal Family Violence. 25, 619-625. http://dx.doi.org/10.1007/s10896-010-9315-7

College of The Bahamas. (2011, November).
Violence symposium. Papers presented at the Violence Symposium, The College of The Bahamas, Nassau, Bahamas. Retrieved from http://www.cob.edu.bs/

Research/ViolenceSymposium/

Craton, M., \& Saunders, G. (1992-2000). Islanders in the stream: A history of the Bahamian people (Vols. 1-2). Athens: University of Georgia Press.

D’Avanzo, C. E. (Ed.). (2008). Pocket guide to cultural health assessment. (4th ed.). St. Louis, MO: Mosby.

Eminem. (2010, August 5). Love the way you lie [Video file]. Retrieved from http://youtu.be/uelHwf8o7_U

Flake, D., \& Forste, R. (2006). Fighting families: Family characteristics associated with domestic violence in five Latin American countries. Journal of Family Violence, 21(1), 19-29. http://dx.doi.org/ 10.1007/s10896-005-9002-2

Fielding, W. J. (2008). Attitudes and actions of pet caregivers in New Providence, The Bahamas, in the context of their American counterparts. Anthrozoös, 21(4), 351-361. http://dx.doi.org/10.2752/175303708X371573

Fielding, W. J., \& Plumridge, S. (2010). The association between pet care and deviant household behaviours in an AfroCaribbean, college student community in New Providence, The Bahamas. Anthrozoös, 23(1), 69-78. http://dx.doi.org/ 10.2752/175303710X12627079939224

Flynn, C. (1999a). Animal abuse in childhood and later support for interpersonal violence in families. Society and Animals, 7, 161172. http://dx.doi.org/10.1163/ 156853099X00059

Flynn, C. P. (1999b). Exploring the link between corporal punishment and children's cruelty to animals. Journal of Marriage and the Family, 61, 971-981. http://dx.doi.org/10.2307/354017 
Gokhale, A. A. (1995). Collaborative learning enhances critical thinking. Journal of Technology Education, 7(1). Retrieved from http://scholar.lib.vt.edu/ejournals/JTE /v7n1/gokhale.jte-v7n1.html

Hahnlen, N. C., Rosado, M. S., Capozzi, K. A., \& Hamon, R. R. (1997, November). Mothering in The Bahamas: A student ethnography. Paper presented at the 59th Annual National Council on Family Relations Conference, Arlington, Virginia. Retrieved from http://files.eric.ed.gov/ fulltext/ED417004.pdf

Hanna, C. (2011). Reducing murders in The Bahamas, A strategic plan based on empirical research. Nassau, Bahamas: Royal Bahamas Police Force. Retrieved from http://www.bahamaslocal.com/files /Reducing_Murders_in_The_Bahamas.pdf

Henning, K., Jones, A., \& Holdford, R. (2005). "I didn't do it, but if I did I had a good reason”: Minimization, denial, and attributions of blame among male and female domestic violence offenders. Journal of Family Violence, 20(3), 131139. http://dx.doi.org/10.1007/s10896-0053647-8

Holt, S., Buckley, H., \& Whelan, S. (2008). The impact of exposure to domestic violence on children and young people: A review of the literature. Child Abuse \& Neglect, 32, 797-810. http://dx.doi.org/ 10.1016/j.chiabu.2008.02.004

Huemer, M. (2003). Is there a right to own a gun? Social Theory \& Practice, 29(2), 297324. http://dx.doi.org/10.5840/ soctheorpract200329215

Humane Society of the United States. (2011). Animal cruelty and human violence. A documented connection. Retrieved from http://www.humanesociety.org/issues/abus e_neglect/qa/cruelty_violence_connection_ faq.html
International Centre for Prison Studies. (2013). World prison brief. Retrieved from: http://www.prisonstudies.org/worldprison-brief

Kim, K. (2012). The role of culture in theories of the intergenerational transmission of violence. Child and Family Social Work, 17, 395-405. http://dx.doi.org/10.1111/ j.1365-2206.2011.00793.x

Lazenbatt, A. (2010). The impact of abuse and neglect on the health and mental health of children and young people. Retrieved from http://www.nspcc.org.uk/ Inform/research/briefings/impact_of_abuse _on_health_pdf_wdf73369.pdf

Le Franc, E., Samms-Vaughan, M., Hambleton, I., Fox, K., \& Brown, D. (2008). Interpersonal violence in three Caribbean countries: Barbados, Jamaica, and Trinidad and Tobago. Pan American Journal of Public Health, 24(6), 409-421. http://dx.doi.org/10.1590/S102049892008001200005

Lenta, P. (2012). Corporal punishment of children. Social Theory \& Practice, 38(4), 689-716. http://dx.doi.org/10.5840/ soctheorpract 201238437

Mass, C., Herrenkohl, T. I., \& Sousa, C. (2008). Review of research on child maltreatment and violence in youth. Trauma, Violence \& Abuse, 9, 56-67. http://dx.doi.org/10.1177/15248380073111 05

McEwen, F. (2010). Animal abuse, child abuse, domestic violence: Research review. Community Care Inform. Retrieved from http://www.ccinform.co.uk/research/anima l-abuse-child-abuse-and-domesticviolence/

McPhedran, S. (2009). Animal abuse, family violence, and child wellbeing: A review. Journal of Family Violence, 24, 41-52. http://dx.doi.org/10.1007/s10896-008- 


\section{6-3}

Mejia, P. (2014, December 6). Ferguson, Eric Garner protests spread worldwide. Newsweek. Retrieved from http://www.newsweek.com/ferguson-ericgarner-protests-sprawl-worldwide-289867

Missick, R. (2014, March 10). Bahamians speak out against domestic abuse remarks. The Tribune. Retrieved from http://www.tribune242.com/news/2014/ma r/10/bahamians-speak-out-againstdomestic-abuse-remarks

National Institute of Justice. (2013). Gun violence. Retrieved from http://www.nij.gov/topics/crime/gunviolence/Pages/welcome.aspx

Nicolls, D., Russell-Smith, C., DeanPatterson, S., Deveaux-Stuart, L. D., Gibson-Mobley, I., Williams, E. J, PinderDarling, A., \& Fielding, W. J. (2014). Attitudes of high school students regarding intimate relationships and gender norms in New Providence, The Bahamas. The International Journal of Bahamian Studies, 20(1), 38-51. Retrieved from http://dx.doi.org/10.15362/ijbs.v20i1.225

Oas, P. T. (2010). Current status on corporal punishment with children: What the literature says. American Journal of Family Therapy, 38(5), 413-420. http://dx.doi.org/ 10.1080/01926187.2010.514214.

O'Hear, M. M. (2013). Mass incarceration in three Midwestern states: Origins and trends. Valparaiso University Law Review, 47(3), 709-753.

Paquette, M. (2004). Violence education: Dissolving the denial. Perspectives in Psychiatric Care, 40(4), 131-132. http://dx.doi.org/10.1111/j.17446163.2004.tb00009.x

Sedlak, A. J., Mettenburg, J., Basena, M., Petta, I., McPherson, K., Greene, A. \& Li,
S. (2010). Fourth National Incidence Study of Child Abuse and Neglect (NIS-4):

Report to Congress. Washington, DC: U.S. Department of Health and Human Services, Administration for Children and Families.

Smith, D. E., \& Mosby, G. (2003). Jamaican child-rearing practices: The role of corporal punishment. Adolescence, 38, 369-381.

Trading Economics. (2015). Bahamas visitor arrivals 2004-2015. Retrieved from http://www.tradingeconomics.com/bahama s/tourist-arrivals

UNICEF. (2003). A league table of child maltreatment deaths in rich nations. Innocenti Report Card, 5. Retrieved from http://www.unicef-irc.org/publications/ pdf/repcard5e.pdf

UNICEF. (2014). Hidden in plain sight: A statistical analysis of violence against children. New York: Author. Retrieved from http://data.unicef.org/corecode/ uploads/document6/uploaded_pdfs/coreco de/VR-full-report_Final-LR3_2_15_189.pdf

United Nations Development Programme. (2015). Human development project data, 2014. Retrieved from http://hdr.undp.org/en/data

United Nations Office on Drugs and Crime, \& World Bank. (2007). Crime, violence, and development: Trends, costs, and policy options in the Caribbean. Washington, DC: World Bank. Retrieved from http://go.worldbank.org/HDBCAXW850

United Nations Office on Drugs and Crime. (2013). Global study on homicide: Trends, contexts, data. Retrieved from http://www.unodc.org/documents/gsh/pdfs/ 2014_GLOBAL_HOMICIDE_BOOK_we b.pdf 
United Nations Office on Drugs and Crime. (2014, May 15). Crime and criminal justice statistics. Retrieved from https://www.unodc.org/unodc/data-andanalysis/statistics/crime.html

Violence Policy Center. (2014). Black homicide victimization in the United States: An analysis of 2011 homicide data. Retrieved from http://www.vpc.org/studies/blackhomicide 14.pdf
Walker, B., Ballance, V., Pinder-Darling, A., Morris, L. \& Bain, E. (2011, November). Violence in The Bahamas and the Caribbean: A bibliography. Paper presented at the Violence Symposium, The College of The Bahamas, Nassau, Bahamas. Retrieved from http://www.cob.edu.bs/Research/Violence Symposium/ViolenceSymposium2011_Vio lenceBibliography.pdf 